\title{
IMMOBILIZATION OF LIPASE ON MESOPOROUS MOLECULAR SIEVE MCM-48 OBTAINED USING IONIC SOLID AS A STRUCTURE DIRECTOR AND ESTERIFICATION REACTION ON SOLVENT-FREE
}

Catia S. Z. Battiston ${ }^{\mathrm{a}, *}$, Aline M. M. Ficanha ${ }^{\mathrm{b}}$, Katarine L. D. Levandoski ${ }^{\mathrm{b}}$, Bernardo A. da Silva ${ }^{\mathrm{b}}$, Suellen Battiston , Rogério M. Dallago ${ }^{\mathrm{b}}$ and Marcelo L. Mignoni ${ }^{\mathrm{b}}$

aInstituto Federal do Rio Grande do Sul, 999713-028 Erechim - RS, Brasil

bDepartamento de Química, Universidade Regional Integrada do Alto Uruguai e das Missões, 99709-910 Erechim - RS, Brasil

'Departamento de Engenharia Química, Universidade Federal de Santa Catarina, 88040-970 Florianópolis - SC, Brasil

Recebido em 01/09/2016; aceito em 06/12/2016; publicado na web em 10/02/2017

\begin{abstract}
Candida antarctica lipase B (CALB) is an enzyme able to catalyze chemical reaction, however when it is used as a free enzyme, it cannot be recovered from reaction medium. One of the alternatives is to immobilize the enzymes on a support which allows the maintenance of their catalytic activities. The purpose of this paper was to immobilize the CALB on MCM-48 using the ionic solid $\left[\mathrm{C}_{16} \mathrm{MI}\right] \mathrm{Cl}$ as structure director. $2^{2} \mathrm{CCRD}$ (Central Composite Rotational Design) was proposed to analyze the influence of the variables like enzyme mass $(0.059$ to $0.341 \mathrm{~g})$ and ionic solid concentration ( 0.59 to $3.41 \%)$ in the enzyme immobilization process to obtain the maximum esterification activity in order to optimize the process. After immobilization, the study results showed that the enzymes exhibited improvement of thermal $\left(40,60\right.$ and $80^{\circ} \mathrm{C}$ ) and storage stability ( 90 days), besides the possibility to reuse of the enzyme up to 10 times, showing residual activity of $50 \%$.
\end{abstract}

Keywords: lipase; immobilization; MCM-48; ionic solid.

\section{INTRODUCTION}

Lipase is a biocatalyst known for versatility and efficiency due to its high activity and stability. It has low toxicity and also regiospecific characteristics, which allow it to obtain products with high purity levels without causing environmental impacts. ${ }^{1}$ Related to application, lipase produced by Candida sp. is receiving featured, especially the one called B produced by Candida antarctica (CALB). ${ }^{2}$

Free enzyme has industrial application limited due to its low stability and difficulty of recovering and reusing it, increasing the economic costs of the processes, as well as promoting the product contamination through residual enzymatic activity. Those problems can be solved using immobilized enzyme, which allows the biocatalyst reuse several times, decreasing the costs and improving the quality of the final product. ${ }^{3}$

The material MCM-48 is a cubic phase molecular sieve which has a three-dimensional channels arrangement with two continuous interpenetrating networks of chiral channels, ${ }^{4,5}$ besides uniform mesopores around $2 \mathrm{~nm} .{ }^{6}$ Due to its structure, it has propitious mass transfer kinetics with potential application in catalysis. ${ }^{7}$ MCM-48 is showing several applications, amongst these the utilization as enzymatic support has been studied. ${ }^{8,9}$

Zeolites and mesoporous material synthetized with ionic liquids or molten salts at ambient temperature has been receiving attentions the last years, ${ }^{10,11}$ due to their properties and important characteristics, making possible their application based on the principles of Green Chemistry, aiming clean chemical process and environmentally friendlies. ${ }^{12}$ These materials act as a structure directing agent, essential reagents responsible for the formation of the material structure, making them a new option to synthesize the mesoporous material.

The purpose of this paper was to investigate and to optimize the Candida antarctica lipase B (CALB) immobilization process on MCM-48 synthetized using ionic solid $\left[\mathrm{C}_{16} \mathrm{MI}\right] \mathrm{Cl}$ as structure director,

*e-mail: catia.zanchett@erechim.ifrs.edu.br which is a ionic solid at synthesis temperature of the immobilized derivative from MCM-48.

For our knowledge till this moment, there are no published studies that perform the enzyme immobilization on MCM mesoporous supports employing the in situ technique, with the addition of the enzyme during the synthesis of the material. From the use of this methodology is possible to capture of the enzyme inside the crystal lattice and consequently hamper their leaching. Furthermore, there are no reports in the literature regarding the use of the solid ionic $\left[\mathrm{C}_{16} \mathrm{MI}\right] \mathrm{Cl}$ (1-hexadecyl-3-methylimidazolium chloride) as a structure directing agent to synthesize the MCM-48 material. Thus, in situ enzyme immobilization onto mesoporous MCM-48 support using solid ionic $\left[\mathrm{C}_{16} \mathrm{MI}\right] \mathrm{Cl}$ as a structure director becomes an original study.

\section{EXPERIMENTAL}

\section{Enzyme and chemical products}

Ionic Solid was synthetized using 1-methylimidazolium (99\%, Aldrich), 1-chlorohexadecane (95\%, Aldrich), acetonitrile $(99,5 \%$, Vetec) e ethyl acetate $(99,5 \%$, Vetec). The support was synthetized using as silica precursor the tetraethyl orthosilicate (TEOS) $(98 \%$, Aldrich), ammonium hydroxide (Quimex), ethyl alcohol (99,5\%, Merck) and deionized water. The enzyme used on this immobilization process was the Candida antarctica lipase B (CALB) in its commercial form (Novozyme). In order to determine the esterification activity were used ethyl alcohol (99,5\%, Merck), acetone $(99,5 \%$, Merck), oleic acid (88\%, Synth), sodium hydroxide (P.A Synth) and distilled water.

\section{Ionic solid synthesis}

The 1-hexadecyl-3-methylimidazolium chloride, $\left[\mathrm{C}_{16} \mathrm{MI}\right] \mathrm{Cl}$, was prepared using methylimidazole $(0.2 \mathrm{~mol})$ and 1 - chlorohexadecane $(0.2 \mathrm{~mol})$ and $30 \mathrm{~mL}$ of acetonitrile, all of them were added into a 
$500 \mathrm{~mL}$ flask. The reaction has occurred under reflux using magnetic stirrer and heating $\left(120{ }^{\circ} \mathrm{C}\right)$ during $48 \mathrm{~h}$; afterward, the flask was cooled until ambient temperature. Another flask was prepared with $500 \mathrm{~mL}$ of ethyl acetate cooled in ethanol and liquid nitrogen, so the $\left[\mathrm{C}_{16} \mathrm{MI}\right] \mathrm{Cl}$ precipitation occurred when the liquid from the first flask was added slowly in the second flask, the whole second flask solution was carried toward a freezer for $24 \mathrm{~h}$, ending the precipitation of the compound.

Ionic solid synthetized was used as structure directing agent in the MCM-48 material synthesis with enzyme immobilization in situ.

\section{Enzymatic immobilization in situ}

The Candida antarctica lipase B (CALB) was immobilized in situ on MCM-48. The main advantage of the immobilized enzyme is its reuse, therefore, it is necessary to prevent leaching as much as possible. With this thought in mind, this method was used to immobilize the enzyme by entrapment, keeping the enzyme retained inside the pore, once the immobilization occurs simultaneously with the formation of the crystalline network of the material.

In order to synthesize support the methodology described by Kumar et al. ${ }^{13}$ was followed with some adaptations. According to the concentration defined on experimental design, the ionic solid 1-hexadecyl-3-methylimidazolium chloride was diluted in $25 \mathrm{~mL}$ of deionized water. After dilution, also according to the experimental design, the mass defined of the enzyme was added into the system followed by more $25 \mathrm{~mL}$ of deionized water. Likewise, it was added $50 \mathrm{~mL}$ of absolute ethanol and $12 \mathrm{~mL}$ of $\mathrm{NH}_{4} \mathrm{OH}$, the whole system was stirred during $10 \mathrm{~min}$. Just after, $3.4 \mathrm{~g}$ of TEOS were added and the system was left stirring for more $2 \mathrm{~h}$ at ambient temperature (20$25^{\circ} \mathrm{C}$ ) and $\mathrm{pH}$ 9. The product was washed by centrifugation using aliquots of deionized water until neutralization (neutral $\mathrm{pH}$ ) and then it was kept resting for $24 \mathrm{~h}$ at ambient temperature.

\section{Support characterization}

The diffraction patterns of $\mathrm{X}$ ray were taken on a diffractometer with D-500 Siemens goniometer, the instrument uses an emitter copper tube that emits K-alpha particles $(\lambda=1,54 \AA)$. The $\mathrm{x}$-ray power supply was operated under the condition of $40 \mathrm{kV}$ and $5 \mathrm{~mA}$. XRD measurements were performed by scanning of the region $1^{\circ}>2 \theta>8^{\circ}$ using a $0,05^{\circ} / 2$ s rate and the data were analyzed through the Origin software.

\section{Total protein determination}

Concerning the free enzyme the concentration of total protein was determined by the method of Bradford, ${ }^{14}$ using bovine serum albumin (BSA) as standard. All determinations were carried out in triplicates.

\section{Specific activity}

The specific activity of the free enzyme $\left(\mathrm{U} \mathrm{mg}^{-1}\right.$ protein) was calculated by enzyme activity ratio $\left(\mathrm{U} \mathrm{mL}^{-1}\right)$ and total protein content $\left(\mathrm{mg} \mathrm{mL}^{-1}\right)$.

\section{Esterification activity measurements}

The esterification activity was determined through the synthesis reaction of ethyl oleate, which was synthetized using oleic acid and ethanol at a molar ratio of 1:1 (standard solution), according to the method describe by Ficanha et al. ${ }^{15} 0.1 \mathrm{~g}$ of free or immobilized enzyme was added in $5 \mathrm{~mL}$ of standard solution. The reaction occurred at $40{ }^{\circ} \mathrm{C}$ in a closed flask using rotary shaker during $40 \mathrm{~min} .500 \mu \mathrm{L}$ aliquots, performed in triplicate, were taken from the reaction mixture. $15 \mathrm{~mL}$ of acetone-ethanol solution was added in each sample. Titration with $\mathrm{NaOH} 0,05 \mathrm{~mol} \mathrm{~L}^{-1}$ was the method used to determine the amount of oleic acid that have reacted until the system reach the $\mathrm{pH} 11$. The blank samples were made by mixing $500 \mu \mathrm{L}$ of standard mixture and $15 \mathrm{~mL}$ of acetone-ethanol solution.

Enzyme activity unit was defined as the amount of enzyme that is able to convert $1 \mu \mathrm{mol}$ of fatty acid per minute, calculated by the equation (1).

$$
E A=\frac{\left(V_{b}-V_{a}\right) \times M \times 1000 \times V_{f}}{t \times m \times V_{c}}
$$

where, EA: Esterification Activity $\left(\mathrm{U} \mathrm{g}^{-1}\right) ; \mathrm{V}_{\mathrm{a}}$ : Volume of $\mathrm{NaOH}$ consumed during the sample titration $(\mathrm{mL}) ; \mathrm{V}_{\mathrm{b}}$ : Volume of $\mathrm{NaOH}$ consumed during the blank sample titration $(\mathrm{mL}) \mathrm{M}$ : Molarity of $\mathrm{NaOH}$ solution; $\mathrm{V}_{\mathrm{f}}$ : Final Volume of the reaction medium; t: time (min); $\mathrm{m}$ : free enzyme mass or immobilized enzyme mass $(\mathrm{g}) ; \mathrm{V}_{\mathrm{c}}$ : Aliquot Volume of the reaction medium withdrawal from the titration $(\mathrm{mL})$.

\section{Determination of immobilization yield}

The following equation (2) was used to calculate the yield of the enzyme/support complex:

$$
R(\%)=\frac{E A_{x}}{E A_{o}} \times 100
$$

where, $E A_{\mathrm{x}}$ : total esterification activity of the enzyme/support complex; $E A_{0}$ : total esterification activity that exists in the mass of the free enzyme added into the immobilization

\section{Storage stability}

The enzyme/support and free enzyme storage stability were made at ambient temperature $\left(20-25^{\circ} \mathrm{C}\right)$ and refrigerated temperature (3-5 $\left.{ }^{\circ} \mathrm{C}\right)$. The stability was observed fortnightly until reach the loss of the $50 \%$ of the activity. The results were written as percentage of residual activity, calculated by the equation 3 .

$$
A R(\%)=\frac{E A^{i}}{E A^{0}} \times 100
$$

where $E A^{\mathrm{i}}$ : Esterification Activity at time "i"; $E A^{0}$ : Esterification Activity at initial time.

\section{Thermal stability}

Enzyme/support complex and free enzyme thermal stability were performed through the esterification reaction on samples that remained incubated in kiln during 1 hour at temperature 40,60 e $80^{\circ} \mathrm{C}$. After the incubation time, esterification activity measurements were analyzed at $40{ }^{\circ} \mathrm{C}$. The results were compared to the initial activity.

\section{Operational stability (reuse)}

The operational stability related to reuse was performed on a continuous way, following the methodology described by Ficanha et al. ${ }^{15}$ After reacting for $40 \mathrm{~min}$, the reaction medium was removed from the system, remaining just the solid phase (enzyme/support complex), so the standard solution was re-added (oleic acid and ethanol) and the sample was submitted to a new reaction. When the 
enzyme/support complex has reached residual activity less or equal to $50 \%$ of the initial activity, the reactions stopped to be repeated.

\section{Experimental design}

In order to evaluate the influence of the enzyme mass and the quantity of ionic solid related to the esterification activity and the yield of the enzyme/support complex and thus, optimize the variables, a central composite rotational design (CCRD) $2^{2}$ were performed with four factorial points, four axes and three centrals, using as independent variable $\mathrm{X}_{1}$ that stands for ionic solid $(\%)$ and $\mathrm{X}_{2}$ that stands for mass of the enzyme (g) (Table 2).

\section{Statistical analysis}

The activity esterification results obtained from the experimental design were verified through the analysis of variance and the response surface methodology using Statistica 8.0 Software on Experimental Desing mode.

\section{RESULTS AND DISCUSSION}

\section{Enzyme characteristics}

The Table 1 presents the main characteristics of the enzyme used in the immobilization process.

Table 1. Enzyme characteristics

\begin{tabular}{cccc}
\hline & Activity $(\mathrm{U} / \mathrm{mL})$ & Protein $(\mathrm{mg})$ & $\begin{array}{c}\text { Specific Activity } \\
(\mathrm{U} / \mathrm{mL})\end{array}$ \\
\hline Free CALB & 209.90 & 0.89 & 235.85 \\
\hline
\end{tabular}

The obtained results are important to identify the characteristics of the free enzyme and thus to compare to the immobilized one, mainly its esterification activity of $209.9 \mathrm{U} / \mathrm{mL}$.

\section{Support characterization}

Figure 1 shows the $\mathrm{X}$ ray diffractogram, with and without enzyme, of MCM-48 material synthetized with $\left[\mathrm{C}_{16} \mathrm{MI}\right] \mathrm{Cl}$.

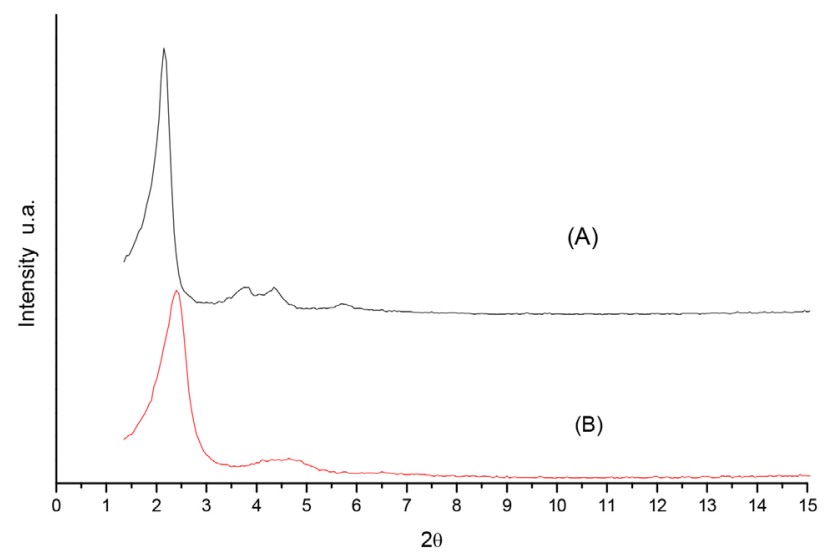

Figure 1. X ray diffractogram: (A) MCM-48 with $\left[C_{16} \mathrm{MI}\right] \mathrm{Cl}$; (B) Enzyme Complex/MCM-48 with $\left[\mathrm{C}_{16} \mathrm{MI}\right] \mathrm{Cl}$

The immobilized support has exhibited the same aspect with respect to the support diffractogram without enzyme. Both diffractogram have peaks that characterize the crystalline material. The peak position (20) identifies the obtained phase as being characteristic to MCM-48 pure and crystalline material, according to the literature. ${ }^{16-18}$

\section{Experimental design}

The assays carried out for different values of enzyme mass and ionic solid that were tested on the central composite rotational design (CCRD), the codified variables $\left(\mathrm{X}_{1}\right.$ e $\left.\mathrm{X}_{2}\right)$, as well as the results obtained from the immobilization are presented on Table 2.

Table 2. Experimental Matrix of the CCRD $2^{2}$ and the results from enzymatic activity

\begin{tabular}{cccc}
\hline Assay & $\mathrm{X}_{1}$ & $\mathrm{X}_{2}$ & $\mathrm{EA}(\mathrm{U} / \mathrm{g}) \pm \sigma$ \\
\hline 1 & $-1(1)$ & $-1(0.1)$ & $162.45 \pm 10.83$ \\
2 & $1(3)$ & $-1(0.1)$ & $41.24 \pm 12.99$ \\
3 & $-1(1)$ & $1(0.3)$ & $164.36 \pm 18.15$ \\
4 & $1(3)$ & $1(0.3)$ & $128.45 \pm 12.36$ \\
5 & $-1.41(0.59)$ & $0(0.2)$ & $136.50 \pm 11.87$ \\
6 & $1.41(3.41)$ & $0(0.2)$ & $131.34 \pm 21.58$ \\
7 & $0(2)$ & $-1,41(0.059)$ & $28.49 \pm 5.03$ \\
8 & $0(2)$ & $1,41(0.341)$ & $43.12 \pm 5.62$ \\
9 & $0(2)$ & $0(0.2)$ & $337.71 \pm 6.09$ \\
10 & $0(2)$ & $0(0.2)$ & $349.18 \pm 53.83$ \\
11 & $0(2)$ & $0(0.2)$ & $346.82 \pm 48.87$ \\
\hline
\end{tabular}

$\mathrm{X}_{1}$ : ionic solid (\%); $\mathrm{X}_{2}$ : enzyme mass $(\mathrm{g})$.

It is observed in Table 2 that by fixing the $\%$ of ionic solid $\left(\mathrm{X}_{1}\right)$ (assay 1 and 3;2 and 4; 7 and 8) and by varying the mass of the enzyme $\left(\mathrm{X}_{2}\right)$ from level -1 to +1 , an increase in the esterification activity (EA) occurred. On the other hand, when the mass of the enzyme is fixed (assay 1 and 2; 3 and 4; 5 and 6) it is observed that with an increase of the $\%$ of ionic solid from level -1 to +1 , a decrease in the enzymatic activity occurred.

The results showed that the enzyme loading has a positive effect on the catalytic activity. On the other hand, negative effect was observed by increasing the ionic solid concentration. The highest esterification activity values were found on the experiments performed on the central points (assay 9, 10 and 11).

The model was validated as observed from the variance analysis, $F_{\text {calculeted }}(20.97)$ bigger than $F_{\text {tabulated }}(5.05)$, and the determination coefficient $\left(\mathrm{R}^{2}\right)$ equal to 0.95449 . The data allow to present the model (equation 4 ) obtained by the coefficient regression as well as to build up the response surface and contour curve show on Figure 2.

When related to the esterification activity of the immobilized supports, all evaluated factors were statistically significant $(\mathrm{p} \leq 0.05)$. Positive linear effect is observed for enzyme mass and, on the other hand, negative effect for ionic solid, the interaction of two variables shows positive effect.

The second order-codified model is presented on equation 4, which describes the activity esterification for immobilization as function of variables enzyme mass and solid ionic perceptual.

$A E=344.41-20.612 x_{1}-95.610 x_{1}^{2}+13.760 x_{2}-144.960 x_{2}^{2}+21.328 x_{1} x_{2}(4)$

The optimum point calculation of the enzyme mass and ionic solid concentration to obtain the maximum esterification activity was developed by equaling the first derivate to zero, according to equation 5 and 6. 
$\frac{d A E}{d x_{1}}=\frac{d\left(344.41-20.612 x_{1}-95.610 x_{1}^{2}+13.760 x_{2}-144.960 x_{2}^{2}+21.328 x_{1} x_{2}\right)}{d x_{1}}=0$

$\frac{d A E}{d x_{2}}=\frac{d\left(344.41-20.612 x_{1}-95.610 x_{1}^{2}+13.760 x_{2}-144.960 x_{2}^{2}+21.328 x_{1} x_{2}\right)}{d x_{2}}=0$

The maximum esterification activity from the mathematic model were obtained on level -0.103345 to the ionic solid concentration and +0.03986 to the enzyme mass. The real values corresponding to those levels are $1.90 \%$ of ionic solid and $0.20 \mathrm{~g}$ of enzyme, what also could be seen on the response surface (Figure 2).

From the optimized points described by the model and showed on the response surface, a new immobilization was performed to confirm the predicted values and the enzyme/support complex was used for the subsequent assays.

\section{Confirmation of the optimum experimental conditions described by the model}

Table 3 shows the results of the experiments performed with the optimum conditions described by the statistical model (1.9 of the ionic solid and $0.2 \mathrm{~g}$ of the enzyme).
Table 3. Tests results of the optimum conditions predicted by the model

\begin{tabular}{ccc}
\hline Experimental Activity $\pm \sigma$ & Predicted Activity & Yield (\%) \\
\hline $469.61 \pm 6.79$ & 345.75 & 822 \\
\hline
\end{tabular}

The experimental activity obtained showed that the use of ionic solid besides being a structure director to the material, it also acts as an additive, showing several effects on the immobilization process like keeping the catalytic activity of the enzyme and increasing the yield.

\section{Storage stability}

Figure 3 describes the behavior of the residual esterification stability to the enzyme/support complex from the points that were optimized on CCRD. In all the tests, free enzyme (FE) were used to produce a comparison. The samples were storage at ambient temperature $\left(20-25^{\circ} \mathrm{C}\right)$ and refrigerated temperature $\left(3-5^{\circ} \mathrm{C}\right)$.

The storage stability for long period is one of the main facts to be considered when immobilized enzymes are being used. The results have showed that the immobilized enzymes have residual activity higher than the free enzyme and the relation does not depend of the
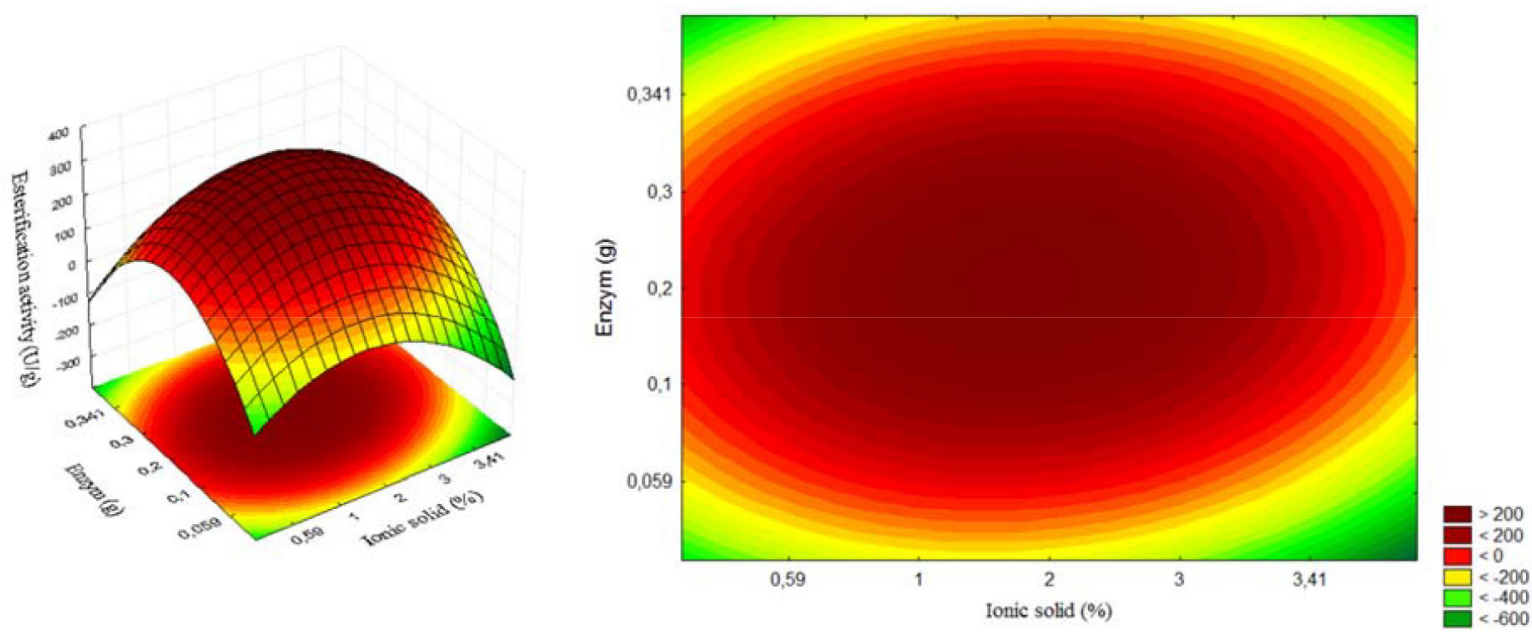

Figure 2. Surface and contour curve from CCRD of the lipase CALB immobilization on $\mathrm{MCM}-48$ with $\left[\mathrm{C}_{16} \mathrm{MI}\right] \mathrm{Cl}$

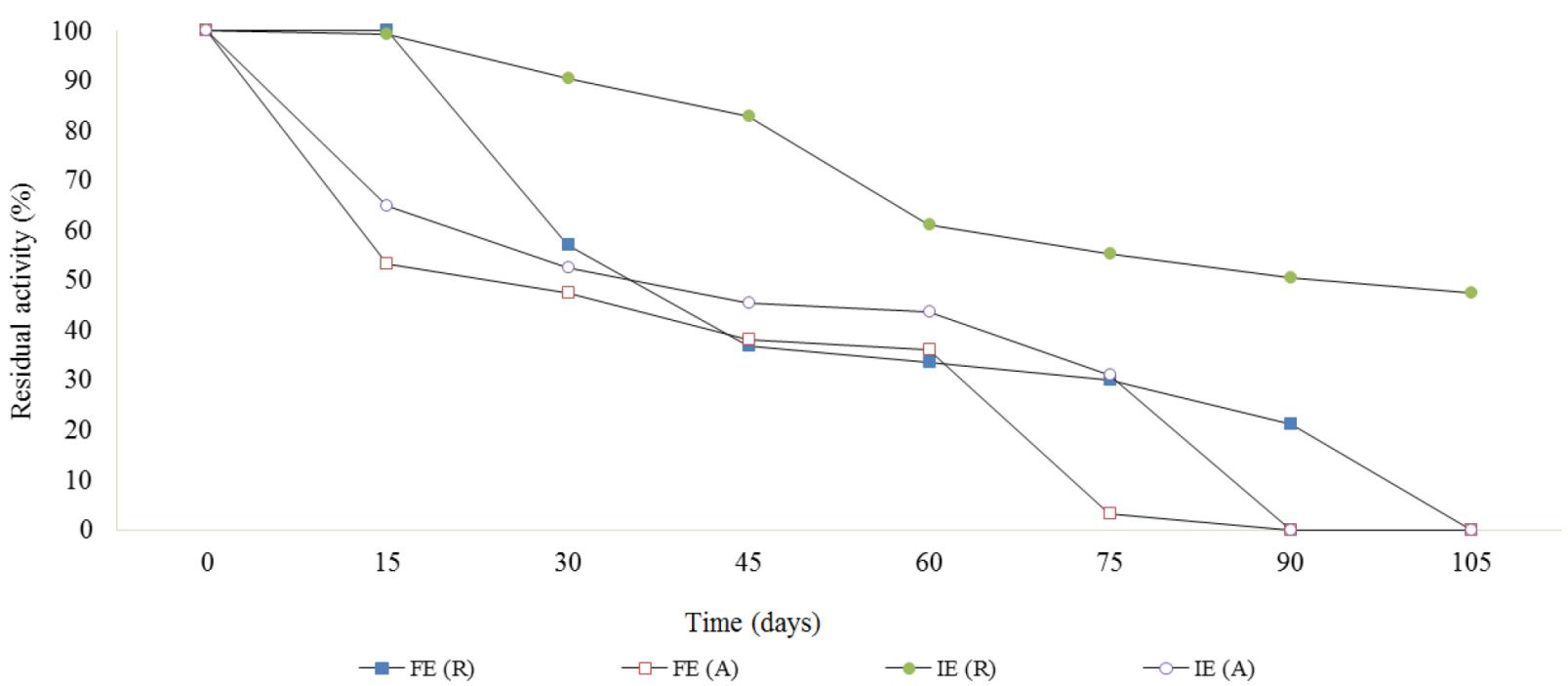

Figure 3. Residual esterification activity of the free enzyme, of the immobilized enzyme storage at refrigerated and ambient temperature. FE: Free Enzyme; IE: Immobilized enzyme; $(R)$ : Storage at refrigerated temperature; $(A)$ : Storage at ambient temperature 
temperature. Considering the storage way, all samples have had same trend; in other words, the residual activity were bigger and had better performance when storage under cooling. When cooled, during 90 days, the immobilized CALB activity was kept in $50.98 \%$ while the free enzyme activity decreased to $7.8 \%$. Even under refrigeration, after 30 days, the free enzyme was disabled considerably.

\section{Thermical stability}

Figure 4 shows the residual esterification activity regarding to the thermal stability of the free enzyme and the enzyme/support complex, which were activated at 40,60 and $80{ }^{\circ} \mathrm{C}$ during $60 \mathrm{~min}$.

Increasing the temperature, free enzyme has showed a reduction on its residual activity. Immobilized enzyme had better results when compared to the free enzyme at different temperatures, indicating a positive effect on the immobilization regarding to the enzyme thermal stability. When the enzyme was carried out at 60 and $80^{\circ} \mathrm{C}$, it lost the biggest part of its initial activity after $60 \mathrm{~min}$, while the immobilized retained $96 \%$ and $44 \%$, respectively, of its initial activity at the same conditions. The data implies that the immobilization procedure had the potential to increase the thermal stability. Similar results were reported by Ficanha et al..${ }^{15}$ that analyzed the thermal stability of the immobilized CALB on xerogels. Souza, ${ }^{19}$ has wrote that immobilized CALB enzyme onto magnetic nanoparticle lost its activity around $20 \%$ after $10 \mathrm{~min}$ at $60{ }^{\circ} \mathrm{C}$ and the free enzyme, under the same conditions, lost more than $70 \%$ of its initial activity. Simões et al. ${ }^{20}$ has studied the thermal stability of the free and the immobilized on chitosan by covalent bonding Candida rugosa lipase and at $50{ }^{\circ} \mathrm{C}$ the free lipase showed $20 \%$ of the residual activity after 60 min of incubation, while the immobilize lipase kept $60 \%$ of the initial activity during the same time condition. In order to be potentially applicable on industrial process, one important parameter to the enzyme is the thermal stability, once a lot of process require temperatures that range 40 till $50{ }^{\circ} \mathrm{C} .{ }^{21}$

\section{Operational stability (reuse)} lipase.

Figure 5 shows the possibility to reuse an immobilize CALB

The reuse of the immobilized enzyme on the support was up to 10 times, considering the residual activity $\geq 50 \%$ of the initial activity. The results have demonstrated that the immobilized CALB on this support had a good reuse capacity, what make it useful to industrial application. Similar results were reported by Ficanha et al. ${ }^{15}$ who have studied the residual activity of the immobilized CALB on xerogels and have obtained 9 reuses on the basic xerogels support. Macario et $a l .^{22}$ also have studied the immobilization of the Rhizomucor miehei (RML) lipase on different zeolitic supports and have obtained 3 reuse cycles. Lei et al. ${ }^{23}$ have immobilized naringinase on MCM-41 support and 6 cycles of reuse were obtained.

\section{CONCLUSION}

The results that were obtained on this study have demonstrated the excellent performance of the CALB lipase, which was immobilized on MCM-48 synthetized with $\left[\mathrm{C}_{16} \mathrm{MI}\right] \mathrm{Cl}$ through optimization of the enzyme mass variable and ionic solid variable.

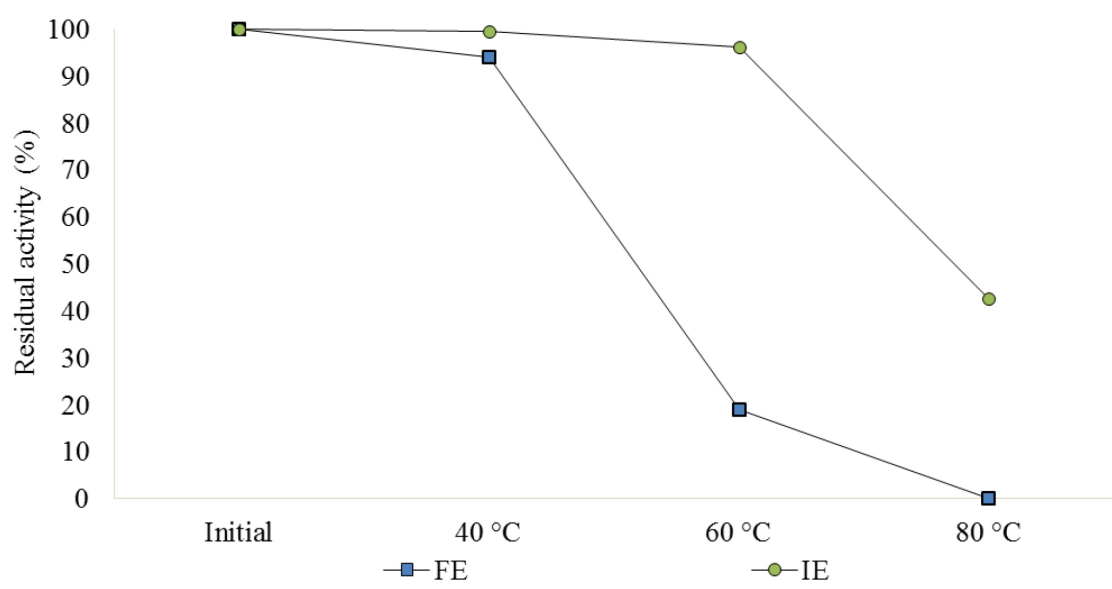

Figure 4. Residual esterification activity at different temperatures. FE: Free Enzyme; IE: Immobilized enzyme

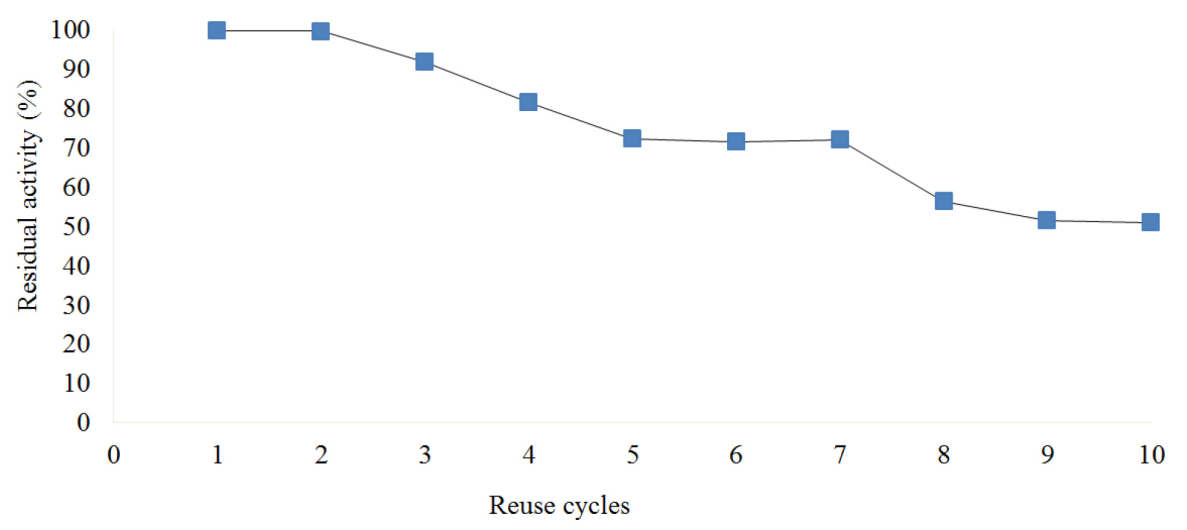

Figure 5. Residual esterification activity of the operational stability 
The immobilization process has provided increase on the thermal stability, storage stability and operational stability in relation to free enzyme. The samples storage under cool conditions showed residual activity of $50,98 \%$ per 90 days, besides the possibility to reuse the immobilized enzyme for up to 10 cycles, considering residual activity of $50 \%$.

\section{ACKNOWLEDGMENTS}

IFRS, Capes, CNPq and URI-Erechim.

\section{REFERENCES}

1. Jaeger, K. E.; Eggert, T.; Curr. Opin. Biotechnol. 2002, 13, 390.

2. Maria, P. D.; Carboni-Oerlemans, C.; Tuin, B.; Bargeman, M. A.; Gemert, R.; J. Mol. Catal. B: Enzym. 2005, 37, 36.

3. Dabdoub, M. J.; Bronzel, J. L.; Rampim, M. A.; Quim. Nova 2009, 32, 776.

4. Hoffmann, F.; Cornelius, M.; Morell, J.; Fröba, M.; Angew. Chem., Int. Ed. 2006, 45, 3216.

5. Yates, T. J. V.; Thomas, J. M.; Fernandez, J. J.; Terasaki, O.; Ryoo, R.; Midgley, P. A.; Chem. Phys. Lett. 2006, 418, 540.

6. Wang, J.; Lu, J.; Yang, J.; Xiao, W.; Wang, J.; Mater. Lett. 2012, 78, 199.

7. Zhang, K.; Yuan, E. H.; Xu, L. L.; Xue, Q. S.; Luo, C.; Albela, B.; Bonneviot, L.; Eur. J. Inorg. Chem. 2012, 2012, 4183.

8. Ping, X.; Guanzhong, L.; Yanglong, G.; Yunsong, W.; Yun, G.; J. Mol. Catal. B: Enzym. 2004, 30, 75.

9. Zhao, B.; Shi, B.; Ma, R.; Eng. Life Sci. 2005, 5, 436.
10. Morris, R. E.; Tian, Y.; Mcpherson, M. J.; Wheatley, P. S.; Z. Anorg. Allg. Chem. 2014, 640, 1177.

11. Sachse, A.; Wuttke, C.; Díaz, U.; de Souza, M. O.; Microporous Mesopororous Mater. 2015, 217, 81.

12. Sharifi, A.; Barazandeh, M.; Abaee, M. S.; Mirzaei, M.; Tetrahedron Lett. 2010, 51, 1852.

13. Kumar, D.; Schumacher, K.; Hohenesche, C. D. F. V.; Grün, M.; Unger, K. K.; Colloids Surf. A 2001, 187-188, 109.

14. Bradford, M. M.; Anal. Biochem. 1976, 248-254, 72.

15. Ficanha, A. M. M.; Nyari, N. L. D.; Levandoski, K.; Mignoni, M.; Dallago, R. M.; Quim. Nova 2015, 38, 364.

16. Schumacher, K.; Grum, M.; Unger, K. K.; Microporous Mesopororous Mater. 1999, 27, 201.

17. Kim, J. M.; Kim, S. K.; Ryoo, R.; Chem. Commun. 1998, 256.

18. León, G. C.; Mercado, Y. A. P.; Cerda, L. A. G.; Silva, J. A. M.; Ortiz, H. I. M.; Maldonado, Y. O.; Contreras, L. A.; Microporous Mesopororous Mater. 2015, 204, 156.

19. Souza, M. C. M.; Tese de Doutorado, Universidade Federal do Ceará, Brasil, 2013.

20. Simões, A. S.; Mori, R. Y.; Faria, R.; Castro, H. F.; Mendes, A. A.; Quim. Nova 2011, 34, 33.

21. Carvalho, N. B.; Barbosa, J. M. P.; Oliveira, M. V. S.; Fricks, A. T.; Lima, A. S.; Soares, C. M. F.; Quim. Nova 2013, 36, 52.

22. Macario, A.; Giordano, G.; Setti, L.; Parise, A.; Campelo, J. M.; Marinas, J. M.; Luna, D.; Biocatal. Biotransform. 2007, 25, 328.

23. Lei, S.; Xu, Y.; Fan, G.; Xiao, M.; Pan, S.; Appl. Surf. Sci. 2011, 257 , 4096. 